COMPANY STRATEGY:

BUSINESS MODEL RECONFIGURATION FOR INNOVATION AND INTERNATIONALIZATION

\author{
Ramon Casadesus-Masanell \\ Joan E. Ricart
}


The Public-Private Center is a Research Center based at IESE Business School. Its mission is to develop research that analyses the relationships between the private and public sectors primarily in the following areas: regulation and competition, innovation, regional economy and industrial politics and health economics.

Research results are disseminated through publications, conferences and colloquia. These activities are aimed to foster cooperation between the private sector and public administrations, as well as the exchange of ideas and initiatives.

The sponsors of the SP-SP Center are the following:

- Accenture

- Ajuntament de Barcelona

- Caixa Manresa

- Cambra Oficial de Comerç, Indústria i Navegació de Barcelona

- Consell de l'Audiovisual de Catalunya

- Departamento de Economía y Finanzas de la Generalitat de Catalunya

- Departamento de Innovación, Universidades y Empresa de la Generalitat de Catalunya

- Diputació de Barcelona

- Endesa

- Fundació AGBAR

- Garrigues

- Mediapro

- Microsoft

- Sanofi Aventis

- VidaCaixa

The contents of this publication reflect the conclusions and findings of the individual authors, and not the opinions of the Center's sponsors. 


\title{
COMPANY STRATEGY: BUSINESS MODEL RECONFIGURATION FOR INNOVATION AND INTERNATIONALIZATION
}

\author{
Ramon Casadesus-Masanell ${ }^{1}$ \\ Joan E. Ricart ${ }^{2}$
}

\section{Abstract}

The competitiveness of a country is the result of the competitiveness of its firms. The competitiveness of firms is partly determined by how their business models interact with the environment to produce offerings with added value. This chapter contributes to the reflection on Catalonia's competitiveness by using the business model concept to highlight the need to adapt business models to new realities in the Catalan environment. Catalan firms have made little effort to reconfigure their business models after being affected by important external shocks. We derive recommendations by presenting and analyzing examples of companies that have innovated in their business models. Business models sit at the core of competitiveness and should be the focus of managers willing to create efficient firms that foster sustained wealth in Catalonia.

Keywords: Strategy, Business, Innovation, Internationalization, Competitiveness, Firms.

\footnotetext{
${ }^{1}$ Professor, Harvard Business School

${ }^{2}$ Professor Strategic Management, IESE
} 


\section{COMPANY STRATEGY: BUSINESS MODEL RECONFIGURATION FOR INNOVATION AND INTERNATIONALIZATION}

\section{Introduction}

The competitiveness of a country is the result of the competitiveness of the firms in that country. The competitiveness of a firm is related to how its business model interacts with the environment, producing an offering that adds value to the participants in this environment. Three elements are important in this statement.

First, added value means that the elimination of the firm and its offering, together with all the incurred costs, reduces overall value. It is well known that a necessary condition for a firm to capture value is that it creates value (Brandenburger and Stuart, 1996). Second, a key determinant of added value is the firm's business model. Third, business models do not act in isolation. They interact with those of other industry participants such as customers, suppliers, competitors, and producers of substitute and complementary products. Exogenous environmental shifts and strategic and tactical moves by other industry players affect the capacity of the firm to continue creating and capturing value.

This paper contributes to the reflection on Catalonia's competitiveness by using the concept of business model to highlight the need to adapt business strategies to important changes in the Catalan business landscape. We argue that Catalan firms have made little effort to adapt their business models to environmental shifts that have affected their ability to create and capture value. To derive recommendations, we present and analyze a number of exceptions: Catalan firms that have had the ability to reconfigure their business models and build sustainable competitive advantage.

The chapter is organized as follows. Section 2 presents our notion of business model. Section 3 develops a representation for the traditional business model of industrial Catalan firms. We also discuss the difficulties that Catalan firms have encountered when interacting with the sudden environmental shifts. Section 4 presents the business models of successful Catalan firms. The last section develops recommendations on how the path to competitiveness can be restored. 


\section{Business Models}

Although there is no generally accepted definition of "business model," practitioners and academics often talk loosely of a business model as "the way the firm operates." While we share this view, we must provide a more concrete definition in order to make progress.

An obvious fundamental component of business models are the concrete choices made by management on how the organization must operate. For example, choices regarding compensation practices, procurement contracts, location of facilities, assets employed, extent of vertical integration, and sales and marketing initiatives are, for the most part, choices made by management that define "the way the firm operates."

Choices, however, are not the sole constituent of business models. They must be connected to value creation and value capture. To do so, we note that, just as causes have effects in the physical world, management choices have consequences. For example, the provision of highpowered incentives (a choice) has implications regarding the willingness to exert effort or to cooperate with co-workers (consequences). Likewise, pricing policies (choices) have obvious implications regarding sales volume which, in turn, affects the intensity and degree of economies of scale and bargaining power enjoyed by the firm (two consequences). Because consequences (such as "low cost" or a "culture of frugality") are usually employed to describe "the way the firm operates," we include them in our definition of a business model. In sum, a business model consists of: a) the set of choices, and b) the set of consequences derived from those choices.

It is helpful to distinguish different types of choices and consequences. There are three types of choices: policies, assets, and governance of assets and policies. Consequences, on the other hand, are classified into flexible and rigid.

Policies refer to courses of action adopted by the firm regarding all aspects of its operation. Examples of policies include: opposing the emergence of unions, locating plants in rural areas, encouraging employees to fly tourist class, providing high-powered monetary incentives, or flying to secondary airports. Assets (physical) refer to tangible resources such as manufacturing facilities or a satellite system for communicating between offices. ${ }^{1}$ By governance of assets and policies we refer to the structure of contractual arrangements that confer decision rights regarding policies or assets. For example, a given business model may contain as a "choice" the use of certain assets such as a fleet of trucks. The fleet can be owned by the firm or leased from a third party. It is well known that seemingly innocuous differences in governance of assets and policies may have a dramatic effect on the effectiveness of a given business model.

\footnotetext{
${ }^{1}$ Note that intangible assets such as experience, brand equity, or even the value of patents are consequences (generally rigid), not choices.
} 


\section{Figure 1}

Elements of a business model

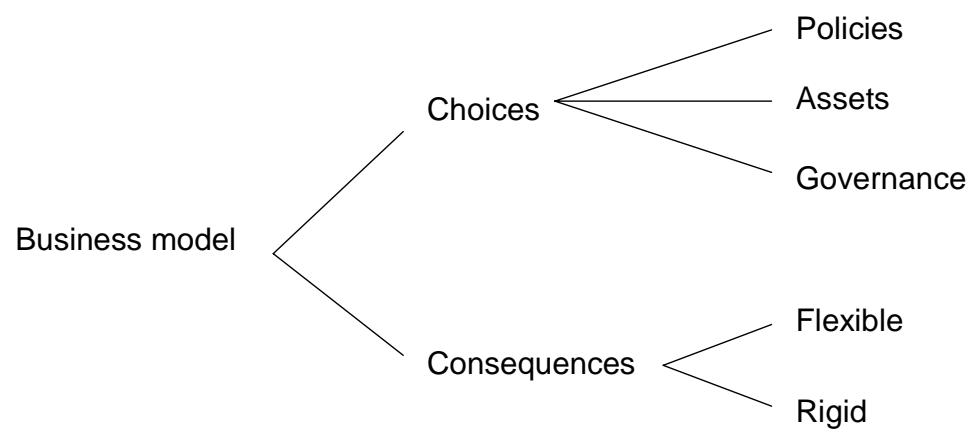

A consequence is flexible if it is sensitive to the choices that generate it. For example, "large volume" is a consequence of a policy of low prices. If the policy changes to one of high prices, volume is likely to fall rapidly. In contrast, a rigid consequence is one that does not change rapidly with the choices that generate it. For example, a "culture of frugality" is a consequence that changes slowly with the choices that generate it. Perhaps a more tangible example is an "installed base of PCs" which is (partly) a consequence of prices set by Intel and Microsoft for the microprocessor and the operating system, respectively. As prices change, the installed base changes slowly: it is a rigid consequence. Clearly, no consequence is purely flexible or purely rigid. All consequences are somewhere in between; it is a matter of degree.

A useful way to represent business models is by means of a causal loop diagram: choices and consequences linked by arrows representing causality. However, except possibly for the simplest organizations, such a representation rapidly becomes highly complex and often intractable. In principle, one could make the effort of listing every choice made by management (although this would take a very long time). More difficult, perhaps, is to list the set of all consequences of those choices and to spell out exactly how choices (and different combinations of choices) deliver those consequences and how exactly consequences (and different combinations of consequences) enable choices. In most businesses there are large numbers of both. An analysis and evaluation of an organization's business model that takes into consideration every choice and every consequence is just impractical: nothing meaningful can be concluded by considering them in such richness of detail.

To overcome this issue, we work with representations of business models (or models of business models). A business model representation consists of a) choices (generally a subset of all choices); b) consequences (generally a subset of all consequences), and c) theories.

Note the third element: theories. Theories are suppositions on how choices and consequences are related. For example, a theory may be that, as R\&D expenditures increase, products with innovative features are brought to market. In the causal loop diagram, we would have an arrow from "high R\&D expenditures" to "innovative products." In many cases theories are commonly 
accepted relationships open to little discussion. ${ }^{2}$ At other times, however, theories are controversial. In the 1960s, Sam Walton believed that large volumes of merchandise would be bought in rural areas if discount stores were located there. At the time, most people did not share this view. Theories are partly determined by the environment where choices are made. Given the demographic, social and economic conditions at that time, Sam Walton's theory made sense in the United States of the 1960s. Without automobiles or the self-service culture that grew with the supermarkets in the 1940s and 1950s, Sam Walton's theory may have proven to be incorrect. Therefore, environmental aspects affect how choices and consequences are connected.

Note that theories do not appear in the definition of a business model. A business model is composed of choices and consequences, but these are the actual choices and actual consequences as they are objectively related. Business model refers to the real relationships. A business model representation, on the other hand, refers to a model of the business model. A business model representation integrates theories of causality that are believed to be true by the business model analyst. If they later fail to hold up in reality, there will be a break in the logic leading to business model failure (partial or complete).

Our concept of business model is intrinsically dynamic as the relationship between choices and consequences occurs over time. Moreover, some "rigid" consequences are stocks (such as an installed base or cumulative experience) that are built over time. An understanding of the functioning and evaluation of business models requires explicit consideration of the dynamics between choices and consequences.

One of the most striking features of business models is that their dynamics often generate feedback loops. This happens when, in addition to choices yielding consequences, consequences enable choices. Feedback loops can be of two types: virtuous cycles and vicious cycles. Since these are symmetric (every cycle can be virtuous or vicious depending on the direction in which it spins), we focus on virtuous cycles.

Virtuous cycles are feedback loops that, as they spin, strengthen some components of the model. For example, Honda historically set low prices for its motorcycles (a choice), consequences were high volume, high cumulative output which allowed the company to move along the learning curve, and low cost. Low cost (a consequence), in turn, enabled Honda to profitably set low prices (a choice). As the cycle spun again and again, Honda kept lowering prices because (marginal) cost decreased. Using the representation diagram:

\footnotetext{
2 Note that disciplines such as economics, sociology, or psychology are, for the most part, devoted to generating theories. For example, there is a large body of economic literature devoted to understanding how incentives affect performance. These theories are distilled in our business model representation by use of a simple arrow (or a few arrows) connecting choices and consequences. Disciplines look at the arrows with great care but have little concern about how arrows interact with one another and contribute to making the whole of a business model.
} 
Once virtuous cycles get going, they take on a life of their own; just as a fast-moving body is hard to stop because it possesses kinetic energy, ${ }^{3}$ well-functioning virtuous cycles cannot easily be brought to a halt.

\section{Figure 2}

Example of a virtuous cycle

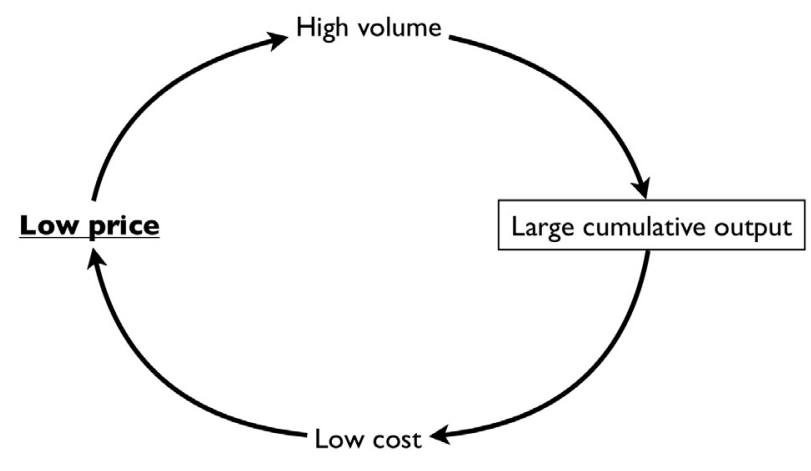

We have defined a business model as a set of choices and the consequences associated with those choices. Clearly, because every organization makes choices and these choices have consequences, every organization has some business model. The obvious question now is: What constitutes a "good" business model? How can we tell a "good" business model apart from a "bad" one? Loosely speaking, a good business model is one that allows the firm to attain its goals sustainably, whatever those may be. Possible goals include, but are not limited to, profit maximization, a better environment, or a pleasant place to work. In Appendix A, we present a framework for the evaluation of business models. ${ }^{4}$

\section{Traditional Business Model of Industrial Catalan Firms}

Traditional industrial Catalan firms had originally developed business models to add value in environments characterized by slow technological change, protected markets, and low-cost labor. In the past few decades, however, the economic, social, and political environment has shifted dramatically. Sadly, there has been little adaptation of business models by Catalan firms. Path dependencies and inertia have characterized their response. The result has been firms unable to thrive in new, dynamic global markets. As a matter of fact, many Catalan firms have been forced out of business by their inability to adapt their models to a changing environment. Entire Catalan industries, such as textiles, have collapsed.

\footnotetext{
${ }^{3}$ Kinetic energy is the energy that a body possesses by virtue of its movement.

${ }^{4}$ For full details on our conceptualization of business models, please see Casadesus-Masanell and Ricart (2008).
} 


\section{Figure 3}

Elements of traditional Catalan business model

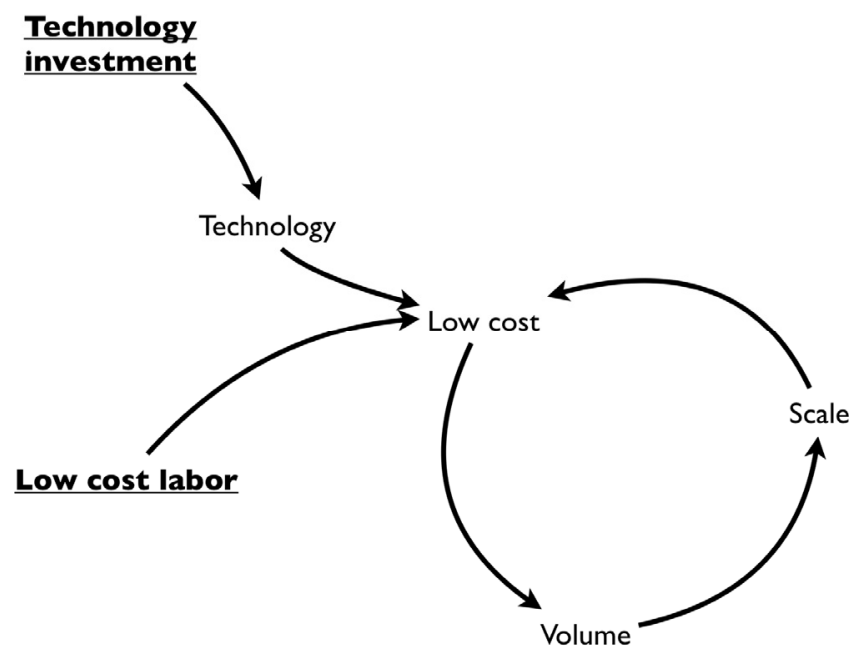

Catalonia joined the industrial revolution earlier than the rest of Spain. This resulted in early mover advantages and superior creation and capture of value, compared to other regions of the country. Figure 3 shows some important elements of the business model during early industrialization. That business model was based on a positive feedback loop radiating from the exploitation of economies of scale, an early investment in technology, and the use of low cost labor (available because of large flows of immigration into Catalonia from other parts of Spain). The environment that Catalan firms confronted was characterized by:

1. Availability of technology, often imported.

2. Low cost labor with sufficient skill to contribute to the simple industrial processes involved.

3. The Spanish local market was sufficiently large for the exploitation of economies of scale. Moreover, protectionism and isolation from foreign competition helped Catalan firms thrive in local markets. Demand grew with Spain's overall economic development.

Figure 4 adds these three features to the representation. We note that availability of technology, low cost labor, and protectionism allowed the business model of traditional Catalan firms to generate sufficient profit for survival. For instance, high prices did not negatively affect volume much because markets were protected and many of the goods produced by these firms satisfied basic needs (and thus the market was assured). In more competitive environments, high prices would have resulted in low volume and high costs: the virtuous cycle would become a vicious cycle. 


\section{Figure 4}

Elements of traditional business model and three features of the economi environment

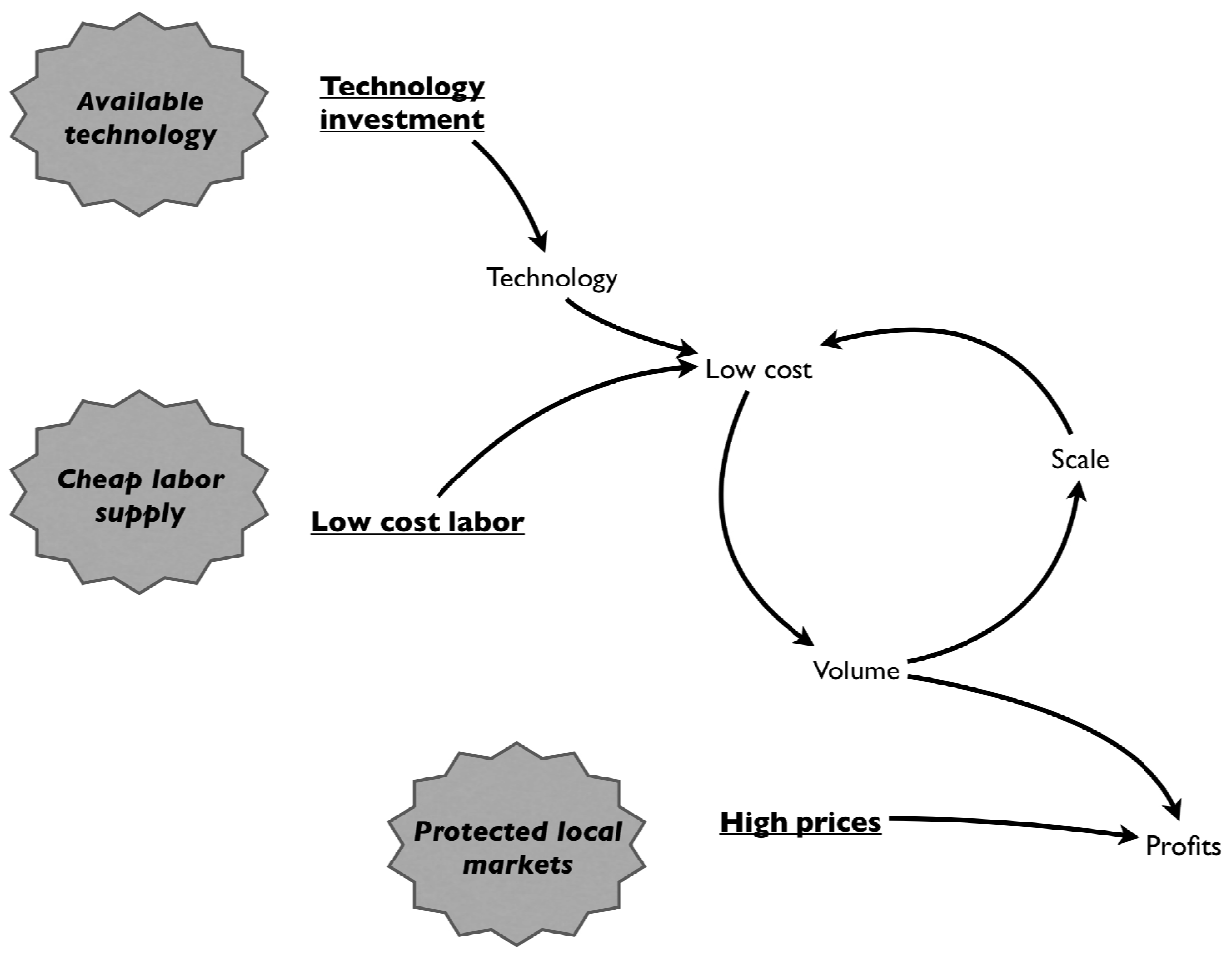

While not explicitly captured by the highly stylized representation of Figures 3 and 4, the traditional business model was coupled with organizational design choices characterized by functional segmentation, hierarchical control, and paternalistic management: an organizational design consistent with the view that individuals are "resources" that should be managed to keep costs low.

Some firms developed more sophisticated business models that featured redundant virtuous cycles and valuable rigid consequences. We highlight three generic sets of additional choices. First, some companies used technologies that displayed important experience effects, where accumulated production was an important rigid consequence. Second, other companies used marketing-related activities to develop branding, customer relationships, reputation, an installed base, or similar rigid consequences that built customer loyalty and created advantages that were robust to environmental changes. Third, other firms used R\&D\&I (research and development and innovation) strategically to improve their products, processes, and even their business models. The rigid consequence in this case was "knowledge" that conferred an innovation advantage. Product innovation and differentiation reinforced the market advantage mentioned above. Figure 5 represents a more sophisticated business model where the focus of innovation is the development of technologies that further reduce costs. 


\section{Figure 5}

Traditional Catalan business model main virtuous cycles

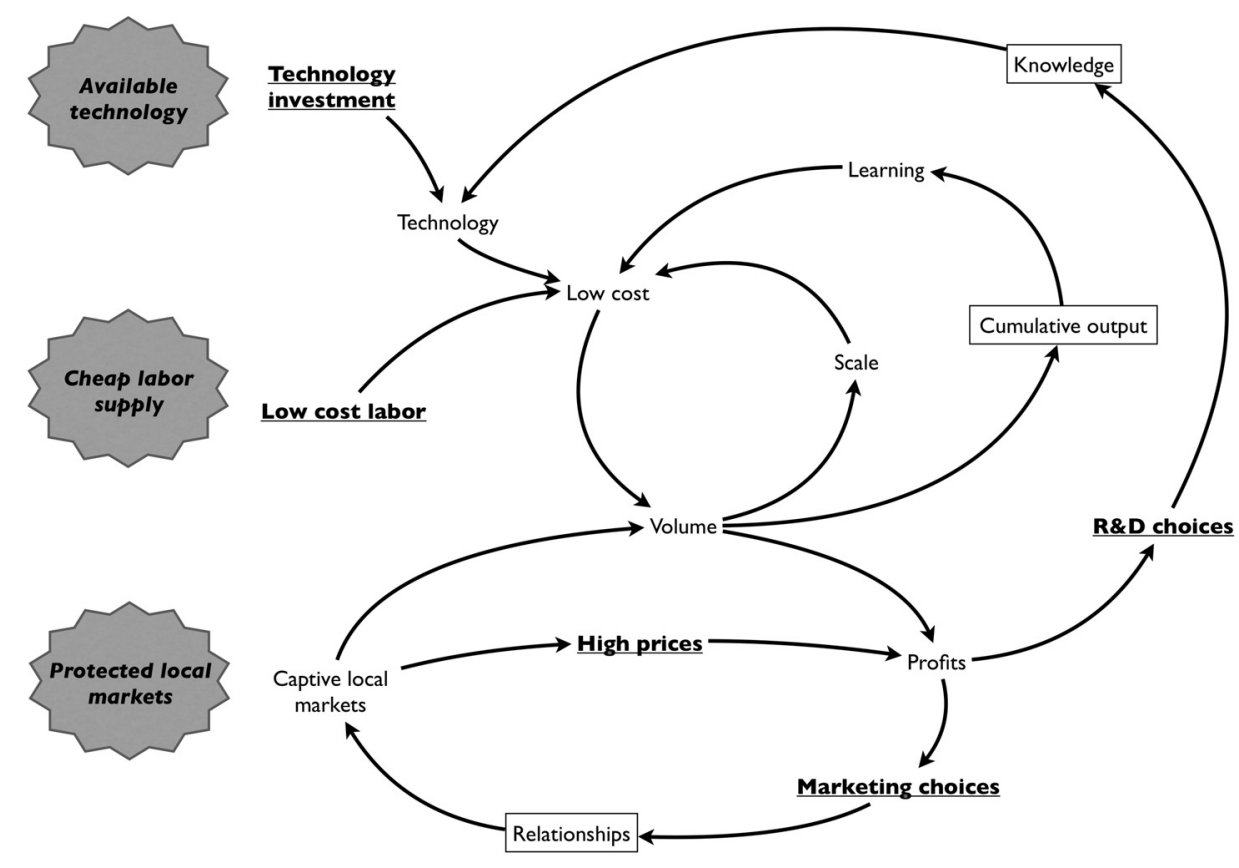

While no two business models are exactly alike, Figure 5 is a good approximation of the dynamics of value creation and value capture of most traditional Catalan firms. As mentioned above, the success of this model was based on early-mover advantages and supported by a flow of low cost labor and market protection. While a few firms complemented these dynamics with a number of feeder choices that strengthened the fundamental loops, the incentives to innovate radically by reconfiguring business models to compete differently were scarce. ${ }^{5}$

In summary, Catalan firms developed simple business models that best responded to an environment characterized by: a) mild strategic interaction that resulted from protectionism; b) assured flow of low-cost labor, and c) available proven technology that had been developed elsewhere. Most Catalan firms conducted limited marketing activities and did little R\&D.

As the environment changed in the 1970s and 1980s and new interactions were brought into play, the old business model became obsolete. The most important changes were: protectionism dwindled, the flow of low cost labor fell off, new technology developed quickly, and marketing activities became a centerpiece of competition. Catalan firms were not able to respond effectively to the more intense competitive interaction brought about by foreign firms entering the Spanish market.

\footnotetext{
${ }^{5}$ Figure 5 is a generic representation of the virtuous cycles generated by the business model of traditional Catalan firms. We note that different firms in different industries stressed different parts of this generic model.
} 
A recent study on the Catalan economy provides support to our argument. ${ }^{6}$ According to Alonso (2007):

«The Catalan economy is immersed in a transformational process from a model based on low costs and fundamentally an internal demand (or external demand of relatively low quality) to a new situation characterized by a need for high quality factors in human, productive and technological capital.»

The author identifies three main forces:

1) A transformation in the industrial network. Spain was increasingly open to international competition and imports while, at the same time, foreign direct investment into Spain decreased. From 1996 to 2006 the ratio of exports over imports decreased from $76.7 \%$ to $62.3 \%$. The negative balance of trade moved from $€ 6,283 \mathrm{M}$ to $€ 28,115 \mathrm{M}$ in the same period.

2) An occupational and industrial restructuring with decreases in industrial labor and dramatic increases in construction and service industries.

3) New demographics and labor market characterized by a worrisome decrease in birth rates and a large rise in immigration flows.

Despite these strong forces for change, few Catalan firms innovated in their business models to improve competitiveness. While there has been some productivity growth in the past few years, most of it has been due to tourism and construction. Real productivity has declined in the period 1996-2006. Per capita GDP has grown at 2.3\% per year. Growth is explained by a $1.45 \%$ increase in the ratio of occupation and 1.3\% in the ratio of activity, while the productivity of labor has declined at the rate of $0.45 \%$ per year.

Genescà and Salas (2007) reach similar conclusions, showing that ex-post competitiveness (ROA minus opportunity costs) grew in this period because of the low growth in labor and financial costs. However, ex-ante competitiveness (measured as productive, technological, human, commercial, relational, and entrepreneurial capital) showed no build-up after 1998, particularly for intangible assets related to R\&D.

In closing this section we should point out that the traditional business model of Catalan firms was quite effective before Spain opened up to foreign competition. New competitors brought new negative interactions, and some of the virtuous cycles in Figure 4 become vicious. Internal demand growth due to a thriving tourism industry delayed the impact of these negative interactions, mitigating the incentives to innovate.

\section{The Path to Competitiveness: Examples}

In this section we present a number of important exceptions to the argument presented in Section 3. We study the business models of Abertis, Applus+, Ficosa, Mango, Metalquimia, and Ros Roca, all companies that built important competitive advantages through reconfigurations

\footnotetext{
${ }^{6}$ We essentially use two chapters, Oliver Alonso (2007) and Genescà and Salas (2007).
} 
in their business models. We use these case studies to derive recommendations that can be applied more broadly.

\subsection{Adaptation to a global industry: Ficosa International S.A. ${ }^{7}$}

Ficosa International S.A., a car component manufacturer, is a paradigmatic example of a Catalan firm that radically changed its business model. Ficosa evolved from a low-tech firm operating solely in Spain to becoming a global player with enviable proprietary technology.

After the end of World War II, Spain suffered an international economic embargo against General Francisco Franco's dictatorship. Lacking a local automobile industry of its own, Spain's isolation led to a severe shortage of car parts. In 1949, Ficosa International was founded with the purpose of supplying replacement brakes, clutches, and speedometer cables. Ficosa quickly responded to its customers' growing needs and expanded its product line. The firm eventually grew into a group of companies producing different car components such as cables, windscreen wipers, rear-view mirrors, sun visors, and window-winding handles. Ficosa evolved until becoming the undisputed market leader in Spain for most of its products.

Initially, Ficosa's business model was based on efficient manufacturing and superior commercial links with local car manufacturing plants, which made the decisions regarding the purchase of components for the models they produced. At the time, Ficosa lacked an R\&D department. Its design was based mostly on copying the products from foreign car component manufacturers. Ficosa was a true example of the simple business model in Figure 4.

Ficosa's business model before 1986 is represented in Figure 6, with choices underlined while consequences are not.

Note the similarities between Figures 6 and 4. There are four main choices: ${ }^{8}$

Proximity to the local customer: allowed Ficosa to identify the customers' needs. Design copy: reinforced low cost manufacturing.

Scale and cheap labor: drivers of low cost manufacturing.

Low price: generated customer satisfaction.

\footnotetext{
${ }^{7}$ This case is extracted from Caldart and Ricart (2008).

${ }^{8}$ At this point it is important to point out that the framework representing this business model identifies key choices that are common to all of Ficosa's business units. Each of the business units also made autonomous strategic choices along other competitive dimensions that, together with the choices embedded in the corporate business model, constituted their competitive strategies.
} 


\section{Figure 6}

Ficosa's simplified business model before 1986

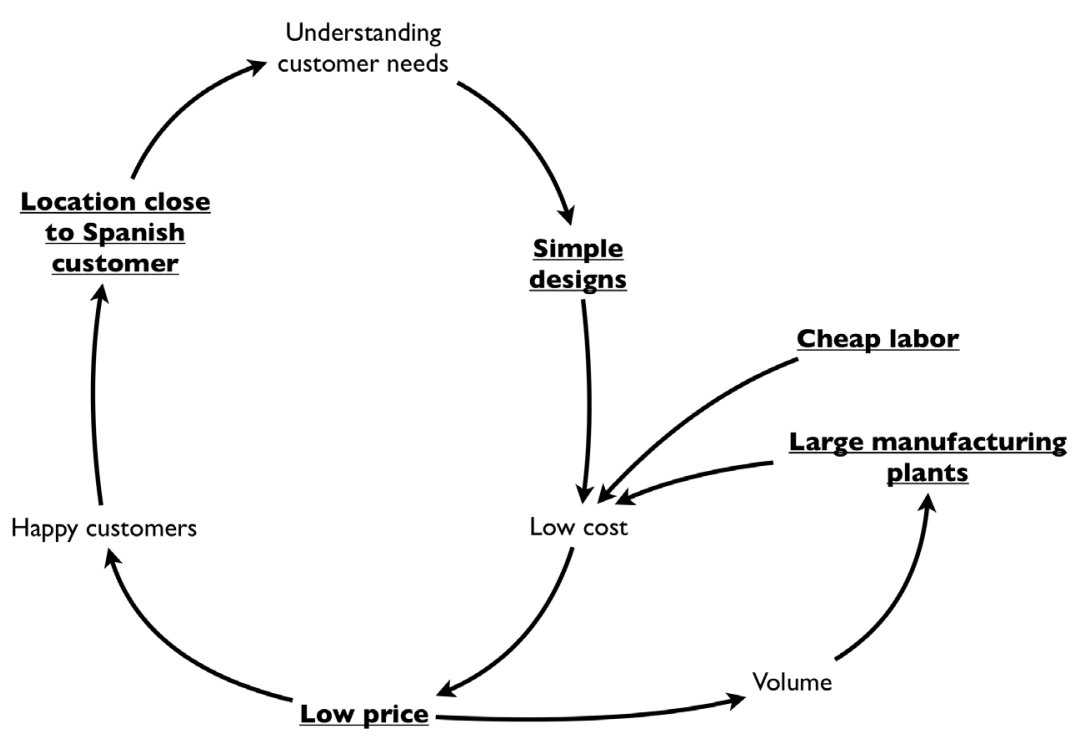

The major shift in Ficosa's strategy began in 1986. On January 1st, 1986, Spain joined the EU (then the EEC), triggering a dramatic shift in the local business landscape. Car manufacturers began to centralize component development in their regional headquarters. They also began to move from spot contracting with multiple suppliers per component to long-term contracts with fewer "technology partners" with whom they developed components and systems. Once component design and development decisions began to be made at the OEM's headquarters, Ficosa's strong commercial relationships with the Spanish plants were no longer a source of advantage. In light of these events, Ficosa's top management realized that, from then on, the natural market space for "tier 1" European component suppliers was no longer their home countries, but the whole of the EU. Companies of European scope would be able to create decisive competitive advantages through economies of scale in manufacturing, R\&D and purchases. To Ficosa these changes presented major challenges. First, the company had to rebuild all of its customer relations virtually from scratch, as it had barely had commercial relationships with the car makers' European headquarters in the past. Second, it had become technology partners of the OEMs, a status that required the development of proprietary R\&D that the company lacked.

After analyzing different possibilities, such as selling the firm or maintaining the current local positioning, the controlling shareholders decided to engage in a European expansion plan aimed at positioning the company as a major European component manufacturer in a five year time frame. The tactic chosen by the company to start its internationalization process was to open engineering centers in each target country (Germany, France, Italy, and the United Kingdom) with the purpose of being close to the large European manufacturers and building the company's reputation as a potential low-cost supplier. However, the company experienced severe financial stress in the late '80s, with the creation of these offices. Orders outside Spain grew only gradually and margins were very tight due to the firm's strategic positioning as a low-cost producer. 


\section{Figure 7}

Ficosa's simplified business model in 1996

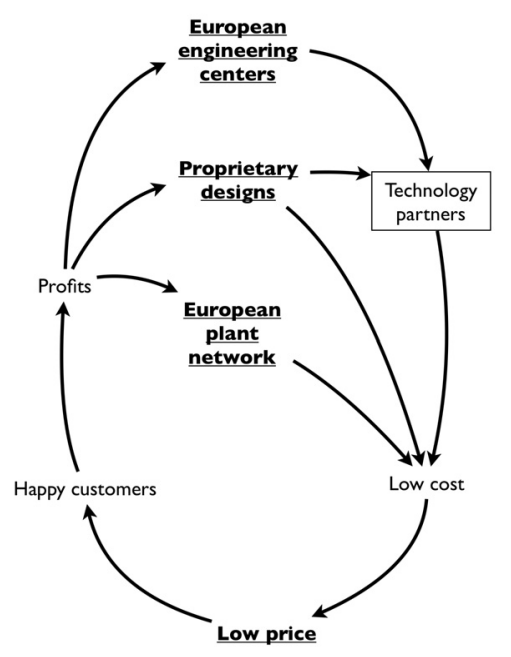

Figure 7 presents the new business model circa 1996. One can easily see that key choices changed radically. The new business model was more complex, it had several (instead of just one) virtuous cycles and an important rigid consequence (boxed): to become a technological partner of European OEMs.

Table 1 highlights the similarities and differences between Ficosa's business model in 1986 and 1996.

\section{Table 1}

Ficosa's transformation - 1986 to 1996

\begin{tabular}{|l|l|}
\hline Business Model choices in $\mathbf{1 9 8 6}$ & Business Model choices in 1996 \\
\hline HQ's proximity to the local customer & $\begin{array}{l}\text { European engineering centers close to } \\
\text { European OEM's HQs }\end{array}$ \\
\hline $\begin{array}{l}\text { Design based on copying competitors } \\
\text { No R\&D }\end{array}$ & Proprietary design. R\&D \\
\hline $\begin{array}{l}\text { Economies of Scale and low labor } \\
\text { cost in Spain }\end{array}$ & European plant system \\
\hline Low price & Low price \\
\hline
\end{tabular}

The first important issue to highlight is the radical change in the firm's business model. Only one choice from the old model remained untouched. Second, choices in 1996 were harder to implement, reflecting the greater challenges associated with operating in a wider and more competitive geographic area. Building European engineering centers, successfully developing proprietary designs or setting up a system of European plants to increase responsiveness were all non-trivial. Finally, the new rigid consequence "technology partner" was a key factor for success. Ficosa's entire European strategy depended on this consequence being built up. Rigid 
consequences built through the convergence of complementary interdependent choices facilitate the sustainability of a business model as they are more difficult to imitate than those resulting from a few independent choices.

By 1995 Ficosa's management was still focused on the goal of consolidating the company as a major European technological partner of car manufacturers. However, new developments taking place in the automobile and component industries gave rise to new challenges. Since the beginning of the 1990s, competition among car manufacturers had intensified, and trimming the cost of supplies had become a central concern of manufacturers.

Despite its European expansion not being complete, in 1995 Ficosa's management realized that global presence was the only way to hold on to its "tier 1" status, and so it decided to embark on a new geographical expansion plan to follow their customers' global expansion and to win new customers worldwide.

As Ficosa moved from European leadership to develop a global position, the essential elements of the underlying business model did not change much, with the exception of the geographic scope. See Table 2.

\section{Table 2}

Ficosa's transformation - 1986 to 2000

\begin{tabular}{|l|l|l|}
\hline $\begin{array}{l}\text { Business Model choices } \\
\text { in } 1986\end{array}$ & $\begin{array}{l}\text { Business Model choices } \\
\text { in } 1996\end{array}$ & $\begin{array}{l}\text { Business Model choices } \\
\text { in } 2000\end{array}$ \\
\hline $\begin{array}{l}\text { HQ's proximity to the local } \\
\text { customer }\end{array}$ & $\begin{array}{l}\text { European engineering } \\
\text { centers close to European } \\
\text { OEM's HQs }\end{array}$ & $\begin{array}{l}\text { Global engineering } \\
\text { centers }\end{array}$ \\
\hline $\begin{array}{l}\text { Design based on copying } \\
\text { competitors. No R\&D }\end{array}$ & Proprietary design. & Proprietary design. \\
\hline $\begin{array}{l}\text { Economies of Scale and } \\
\text { low labor cost in Spain }\end{array}$ & European plant system & Global plant system \\
\hline Low price & Low price & Low price \\
\hline
\end{tabular}

During the period 1986-2002, Ficosa's annual growth rate in sales averaged 23\%. The company established a presence in 18 countries in all the key geographical centers of gravity of the car industry worldwide and expanded its customer base to include every large OEM. Less than 23\% of sales came from Spain in 2001. The number of employees increased from 700 in 1985 to more than 6,000 in 2001 . The company maintained its private status and the majority shareholdings remained in the hands of the same two families that founded it fifty years ago.

Ficosa exemplifies radical business model adaptation in anticipation to changes in the industry as well as the opening of the Spanish market. The old virtuous cycles were about to lose effectiveness due to the new international competition. In anticipation, Ficosa developed new virtuous cycles around the engineering centers, new proprietary designs and, eventually, a network of European plants.

Other leading Catalan companies that underwent similar transformations include Celsa in the steel industry, Puig in perfumes, Codorníu in wines, and Colomer Group in cosmetics. 


\subsection{Anticipate/Adapt to Industry Change: Ros Roca S.A. ${ }^{9}$}

Ros Roca, a family business located in rural Catalonia, began as a small manufacturer that sold hand- and animal-drawn waste collection carriages to Spanish municipalities. It soon transformed itself into a major player in the production of trash collection and cleaning equipment, treatment plants, and pneumatic collection systems, first in Spain and later in Europe and Latin America. A simplified representation of Ros Roca's business model is given in Figure 8.

\section{Figure 8}

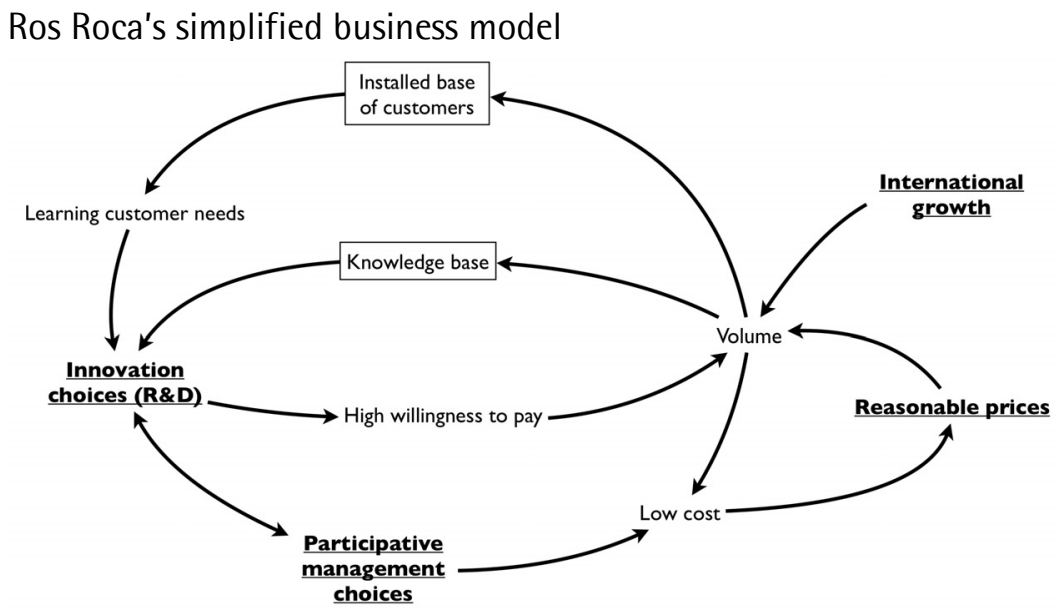

Ros Roca's business model had three distinctive features. First, it placed strong emphasis on innovation. This resulted in a high consumer willingness to pay for its products. Second, the firm pushed early for internationalization. Extensive international exposure strengthened its innovation cycles, provided valuable information on customer needs, and afforded sufficient scale for low cost production. Innovation and internationalization caused the two rigid consequences shown in Figure 8: the installed bases of global customers and knowledge. Third, Ros Roca was willing to experiment and innovate in its manufacturing management system, committing its work force to cost reduction while developing superior products without relying on low salaries. The company applied a novel management system originally developed by the Basque cooperative Irizar, based on worker empowerment and shared rewards. ${ }^{10}$

Ros Roca developed a successful business model able to compete effectively against global competitors. The development of Ros Roca's business model from its origin to steady state was more gradual than Ficosa's because the company got started early on in its innovation and internationalization efforts.

Comparing Ros Roca's business model with the traditional model in Figure 5, we see:

1. The company developed a knowledge-creating virtuous cycle which required proximity to demanding customers and access to dispersed technology. This led to rapid international expansion. To assimilate Ros Roca's fast-growing stock of knowledge and to take

\footnotetext{
${ }^{9}$ For a complete description of the case and the analysis of the business model see Ricart (2009).

${ }^{10}$ See Casadesus-Masanell and Mitchell, (2006).
} 
advantage of it, the firm had to develop excellent absorptive capabilities, far beyond those required for the one-time technology acquisition of the traditional model in Figure 5.

2. Ros Roca quickly generated a large installed base of international customers (in Europe and Latin-America). A large installed base of customers was key for developing innovative products, but also to obtain references, sign in new customers, and explore new markets. Ros Roca was able to overcome the dependence of traditional Catalan firms on protectionism.

3. Low cost, while still important, was not based on the supply of low cost labor. Instead, it was based on a) economies of scale which were exploited thanks to the company's rapid international expansion, and b) participative management and worker empowerment.

4. Ros Roca's business model generated high consumer willingness to pay while keeping costs close to those of competitors.

\subsection{Inventing a New Business Model: Mango ${ }^{11}$}

Mango, a designer, manufacturer, and distributor of clothes and footwear, was 'born international'. The company started importing sophisticated product designs which it manufactured in low cost countries. By exploiting the arbitrage opportunity of sourcing fashionable garments for young, sophisticated customers, Mango was an instant success that reshaped industry practice. The company expanded quickly and moved early into international markets. Mango developed a global brand and a network of exclusive retailers, most of them franchises. Thanks to a complex, tailored IT system and innovative human resource practices, Mango was able to manage growth while keeping costs under control allowing competitive pricing. Figure 9 presents a representation of the most relevant features of Mango's business model.

\section{Figure 9}

Mango's simplified business model

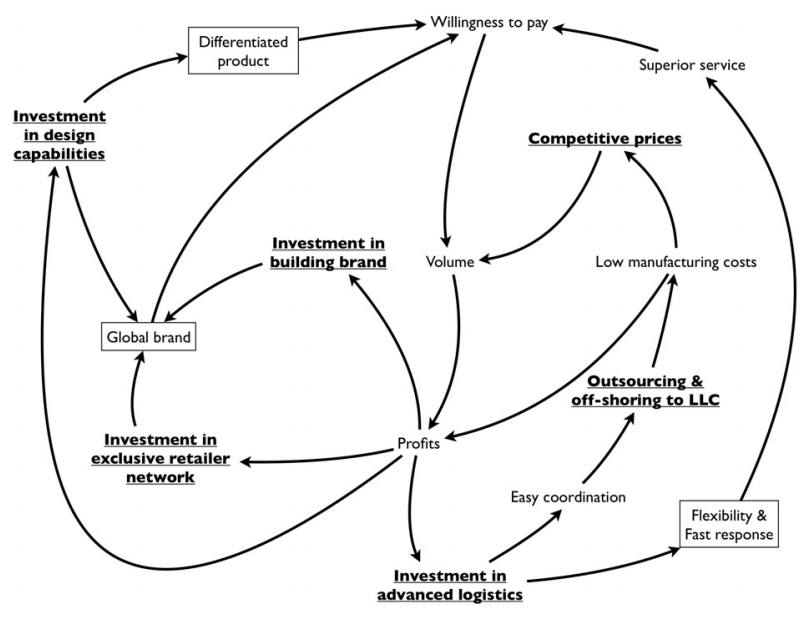

\footnotetext{
${ }^{11}$ For a complete description of the case and the analysis of the business model see Ricart (2009).
} 
Mango's business model anticipated important changes in the way young people approach fashion and their shopping behavior. The company realized that young women all over the world look for good designs and strong brands at low prices. Owing to its innovative use of IT and HR policies, Mango developed an effective business model able to accommodate the tension between branding, distribution, design, and low-cost manufacturing. Just as in the case of Ros Roca, innovation and rapid pace of internationalization were key drivers of competitive advantage for Mango.

Comparing with Figure 5, we observe:

1. Low cost was a fundamental aspect for the working of Mango's model. To reach the right cost level, Mango began importing from low cost countries. Arbitrage through outsourcing and off-shoring was used extensively. Second, Mango realized early on that cost not only accumulated in the physical product but also in all the primary and support activities from design to sale. Mango used sophisticated human resource management policies and IT systems that drastically increased the efficiency of all these activities.

2. Mango invested heavily in marketing activities to create a global brand and an exclusive network of retailers (owned and franchised). These were large investments enabled by the high margins that low cost allowed. As the brand and the network of retailers grew, willingness to pay and value capture improved.

3. To enlarge the wedge between customer willingness to pay and cost, Mango focused its $\mathrm{R} \& \mathrm{D}$ on the creation of a concept that integrates all aspects of a garment, from design to distribution. This helped improve the sustainability of Mango's advantage.

4. Mango was an example of Blue Ocean Strategy (Kim and Maubourgne, 2005). The company developed an offering for a large, new market space, through keeping some attributes of the shopping experience that its target customer group valued (such as high-end fashion garments at reasonable prices), eliminating attributes not valued much by the target customer segment (such as high quality but delicate fabrics or television advertising), and adding new attributes that set the company apart from its competitors (such as loud, modern music in the stores).

In a different industry, Naturhouse (the leading distributor of dietetic and nutrition products in Spain) also developed an innovative business model with similar features. In the case of Naturhouse the key was to develop a credible distribution system through the advice and support services for shoppers provided by a network of professional dietitians that ran the franchise shops.

\subsection{Innovation as a key driver: Metalquimia ${ }^{12}$}

Located in Girona, Spain, and founded in 1971, Metalquimia was a leader in the technology and manufacturing of complete turn-key lines for the production of cooked and marinated meat products. In 2009, its products were used by all over the world in the most important meat processing plants. Right from the beginning, Metalquimia specialized in offering custom-made

\footnotetext{
${ }^{12}$ For a complete description of the case and the analysis of the business model see Ricart (2009).
} 
technological solutions for manufacturing cooked meat products, based on a business philosophy of continuous innovation, service excellence, and total quality. Figure 10 presents a simplified version of its business model.

\section{Figure 10}

Metalquimia's simplified business model

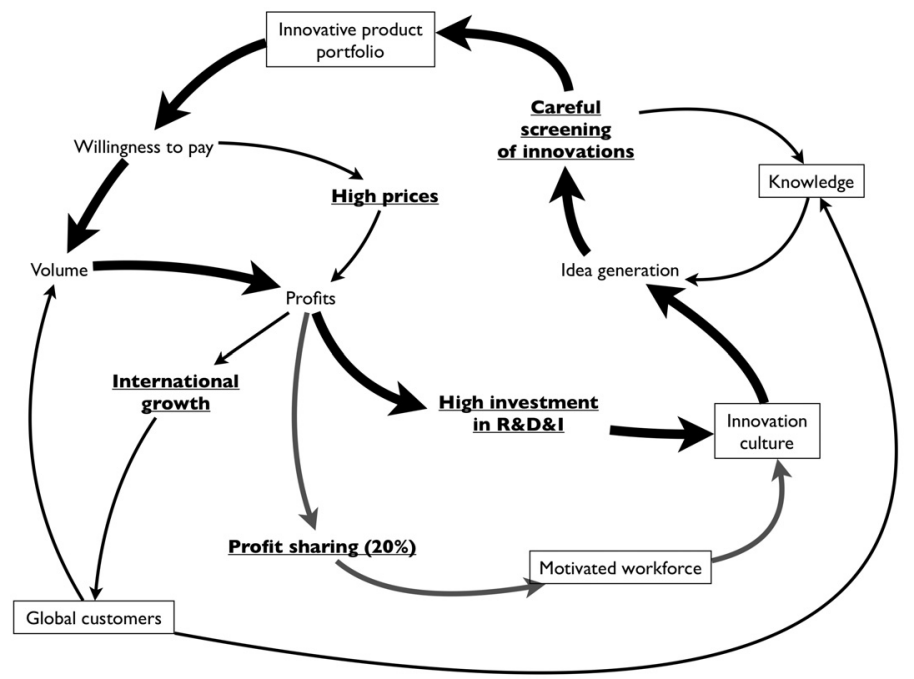

Metalquimia had a sophisticated and focused business model geared towards the creation of a culture of innovation. The company had an effective process for the management of innovation that resulted in a wealth of new products and enviable success in the marketplace. Metalquimia's business model is radically different from that in Figure 5. Metalquimia was not an industrial company that invested in R\&D; it was an innovation company that sold production lines for the production of cooked and marinated meat products. Metalquimia saw itself as a producer not of machinery, but of innovations.

The bold black arrows in Figure 10 show the fundamental virtuous cycle. This is a cycle based on the development of a culture of innovation. The representation is a simplified version of the full, real business. Metalquimia made a large number of choices that encouraged innovation. The company developed a stock of knowledge and ideas. The incentive system was one where people were strongly motivated to contribute and commit to the organization (blue line). The company also built a network of alliances with research centers and universities to further its innovation culture. The company developed tools to select the best ideas put forth by its employees, those with maximal market potential. The company's rate of success - close to 90\% of the ideas selected end up as successful products - was well above industry standard.

Internationalization was a crucial element in Metalquimia's business model. First, being exposed to demanding international customers pushed the company towards superior responsiveness and collaboration. In fact, a large number of Metalquimia's innovations were the result of strategic alliances with key customers. Second, growth in a niche required international expansion. 
Metalquimia's added value was a consequence of the greater willingness to pay associated with their differentiated products. Costs, while somewhat larger than those of competitors, were more than offset by the additional willingness to pay that the company's innovations generated.

An important governance-related aspect of Metalquimia's business model is that it was a family business. The family's commitment to innovation and Catalan culture contributed greatly to its success (as these elements had noteworthy effects on the employees' identification with the company).

\subsection{The creation of a global company: Applus ${ }^{13}$}

In 2002, Catalan industrial group Agbar set up Applus+, a leading global quality certification company. Driven by important demographic changes and the need for quality assurance in many industries, Applus+ grew rapidly through acquisitions to become the third largest certification company in the world, with interests in many industries and countries.

The business model of Applus+ (shown in Figure 11) was based on two main drivers. First, by aggregating businesses in one particular area of expertise or industry and by investing in labs and innovations in this area, the company created a body of knowledge that helped the company improve its offering. Second, by acquiring different businesses in a particular market, together with their marketing campaigns and public relations, Applus+ developed institutional relations and local presence that built trust and confidence in its offering. Once again we see a business model where innovation and internationalization are central to value added.

\section{Figure 11}

Applust's simplified business model

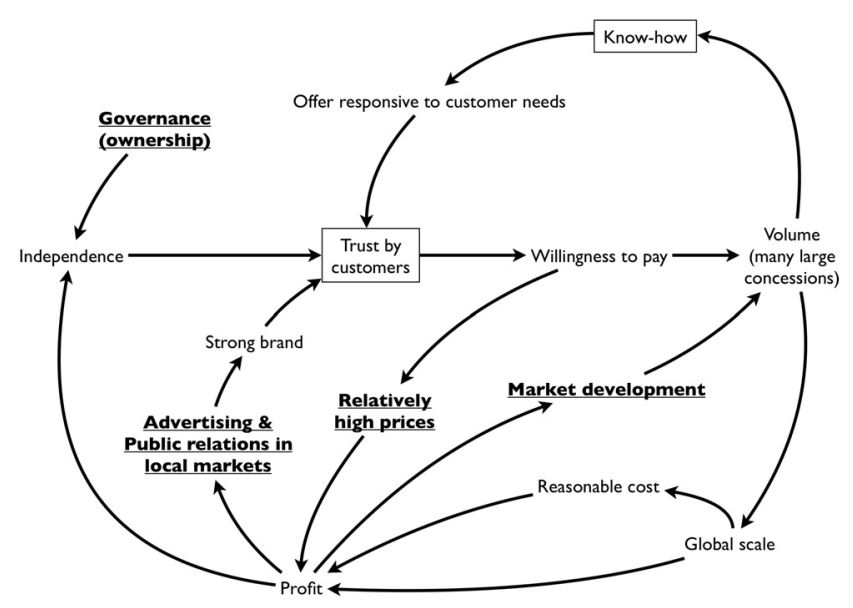

The influence of the parent (Agbar) was not negligible; its financial strength and portfolio of industrial clients helped Applus+ begin its operations, develop and grow fast. After Applus+'s business model was consolidated, Agbar sold the company to a private equity fund.

\footnotetext{
${ }^{13}$ For a complete description, see the case by Ricart (2005).
} 
Not surprisingly, as a company that provided services, Applus+'s business model was markedly different from the traditional industrial model of Figure 5. Applus+'s advantage was based on the trust that it had developed with current and potential customers. Trust depended on knowledge in their area of expertise (initially automotive, but later in other sectors) and local presence (and branding). These elements were reinforced by an ownership structure and financial prowess that instilled independence and impartiality. To develop expertise and local presence, Applus+ invested and grew rapidly so as to exploit first-mover advantages. Applus+'s superior value capture resulted from the company's ability to reduce costs faster than prices under commoditization pressures.

\subsection{The Financial Ambition: Abertis ${ }^{14}$}

Abertis was a company devoted to the management of public infrastructures through publicprivate partnerships. Initially focused on toll roads in Catalonia, it grew to be the world's largest operator of toll roads and later diversified into the management of telecoms infrastructure, airports, car parks, and logistics centers. By 2009, toll roads were the largest revenue and profit generator for the company.

Abertis was set up by "la Caixa," Spain's leading savings bank and its third largest financial institution. Abertis's main shareholders in 2009 were Criteria Caixa Corporation ("la Caixa") and ACS (Actividades de Construcción y Servicios), a leading construction company. Abertis operated in businesses that required large investments and long-term profitability horizons.

\section{Figure 12}

Abertis simplified business model

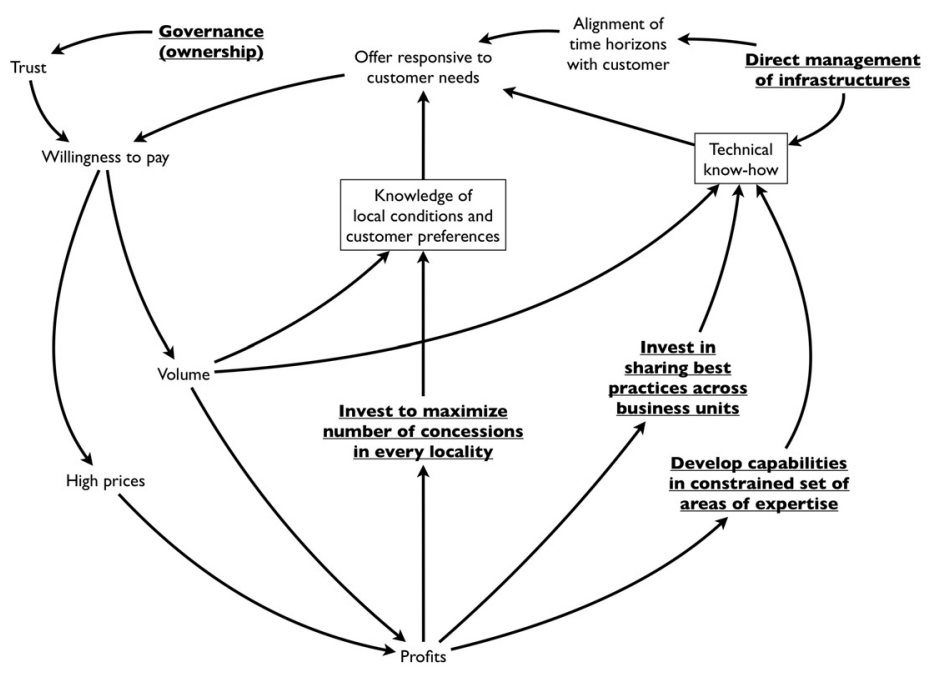

Although the company had many business units, Figure 12 is a good approximation of the fundamental virtuous cycles that their approach to management of infrastructures generated (regardless of the specific business). Similarly to Applus+, Abertis's business model was composed of two important cycles. First, the company chose to offer a reduced product line in

\footnotetext{
${ }^{14}$ For a complete description of the case and the analysis of the business model see Ricart (2009).
} 
as many regions as possible. This allowed the buildup of a stock of knowledge on how to most efficiently manage infrastructures. Second, by having different businesses in the same geographical area, Abertis developed strong relations with important stakeholders and this resulted in increased likelihood of being awarded new concessions. Abertis approached its relationships with customers as long-term public-private partnerships where both sides worked together to create and share value. The case of Abertis once again illustrates that knowledge creation and international expansion go hand in hand.

\section{The Path to Competitiveness: Looking Ahead}

The firms that we have studied made a push for internationalization and/or innovation. Because of the idiosyncrasies of their industries Ficosa, Ros Roca, Mango, Metalquimia, Applus+, and Abertis innovated and internationalized their operations in different ways, but all used both drivers as shown in Table 3. The table highlights the key rigid consequence developed by each business model in each dimension.

\section{Table 3}

Two Common Traits - Innovation and Internationalization

\begin{tabular}{|l|l|l|l|}
\hline Advantage & Company & Innovation & Internationalization \\
\hline COST & FICOSA & Proprietary designs & Global plant system \\
\hline COST & ROS ROCA & $\begin{array}{l}\text { Knowledge base } \\
\text { Differentiated products }\end{array}$ & Installed customer base \\
\hline DIFFER. & MANGO & Differentiated designs & $\begin{array}{l}\text { Global brand, manufacturing, and } \\
\text { distribution network }\end{array}$ \\
\hline DIFFER. & METALQUIMIA & $\begin{array}{l}\text { Knowledge base } \\
\text { Differentiated products }\end{array}$ & Installed customer base \\
\hline VOLUME & APPLUS+ & Knowledge base & Multiple local presence \\
\hline VOLUME & ABERTIS & Expertise in industrial projects & Relationships to local stakeholders \\
\hline
\end{tabular}

Ficosa and Ros Roca are examples of value creation through low cost advantage. Interestingly, low cost is not based on the availability of cheap Spanish labor. Ficosa's business transformation began with the development of proprietary designs. These were used to launch a broad internationalization effort, first of customers and later of sourcing. Ros Roca simultaneously developed innovation and internationalization as the industry evolved from infancy to maturity.

Mango and Metalquimia are examples of value creation through differentiation. Mango was born international and gradually evolved into a designer of highly differentiated garments. Metalquimia did the opposite: it was born innovative and later moved into international markets to sustain its innovation cycles. Both cases had to move quickly on both dimensions, but the sequence and pace was different. 
Applus+ and Abertis's business models are based on growing quickly and achieving scale. Their models require heavy investment. They both had to move into knowledge development and increase business size simultaneously, not only in terms of internationalization but also deepening reach within each geographic area. It is therefore not surprising that Applus+ and Abertis are housed by large industrial groups (Agbar and Criteria, respectively).

The cases demonstrate that there exist paths to competitiveness through business model reconfiguration. New business models set up powerful and robust virtuous cycles that allow firms to create and capture value. Technological progress, globalization, demographic change, and other forces enable the creation of new business models.

While some firms may still profitably focus on local markets (as there may be advantages of localization in the offering or in production when unique local resources are available), the traditional business model, based on cheap local labor and protected markets, will unequivocally lead to failure. The most successful business model transformations of Catalan firms have entailed the development of new virtuous cycles.

Low cost is a strategic requirement for many businesses. However, low costs are reached in different ways today. Off-shoring to low-cost countries of non-core activities, economies of scale and experience through the size reached through internationalization, adoption and development of new technologies, or the use of new management systems with worker empowerment, are just a few paths available to firms.

An important conclusion of our research is that there is no single path to becoming innovative or international. Every one of the firms that we have analyzed has followed a different route. While the particular paths to competitiveness may all be distinct, there are some common traits. The following recommendations can be drawn:

1. Be aware and take advantage of changes in your environment: We have seen that important environmental shifts drastically weaken the cycles in the traditional business model that, originally, were virtuous. At the same time, however, environmental changes present opportunities to innovate. The best response to such changes requires modifications in the business model that are often radical. Ficosa illustrates this point clearly. As the auto industry globalized, Ficosa had to re-invent itself to confront interactions with players in the industry that were different in nature from what the company had experienced before globalization. Mango and Ros Roca took advantage of technological changes to redefine their industries. In all the cases that we have presented, firms' actions went well beyond minor tactical moves to deal with changes in the competitive landscape. They all made important strategic bets that involved redefinitions of their business models.

2. Search for robust virtuous cycles and support them with complementary choices. Welldesigned business models have cycles that fend off standard threats to sustainability as identified by Ghemawat (1991) (imitation, substitution, slack, and hold up). While in this paper we presented simplified representations of business models, every one of them has a large number of complementary choices and cycles that support one another and feed important rigid consequences.

3. Focus on virtuous cycles that generate added value. Business models must respond to the needs of the market that they serve by providing sufficient added value. Every one of the cases that we have presented involves a firm creating value for a particular target 
customer segment. In most cases, value is created through greater willingness to pay without excessive cost increases (compared to competition).

While the firms that we reviewed were able to transform themselves and reconfigure their business models to create competitive advantages, many others did not succeed in this endeavor. A large number of Catalan firms either did not understand the environmental changes, did not have the drive to aggressively invest in innovation and internationalization, were maybe too risk averse, or lacked resources for change (such as managerial talent or capital). And when they tried to transform their business models, it was too late. The window of opportunity had passed.

The obvious question is: how should firms proceed to reconfigure their business models? The following are some recommendations:

1. Identify and nurture the virtuous cycles in your business model that allow your organization to create and capture value. Anticipate changes in the environment that may affect the strength of these important cycles and either protect them through new complementary choices or create new cycles.

2. Identify the vicious cycles that your business model generates and correct them. We should point out that there are two main types of vicious cycles: a) those generated by inconsistencies in the business model, and b) those that have the potential of becoming virtuous through the addition of complementary choices.

3. Business models act in interaction with those of other industry players. To understand and manage this interdependence is therefore fundamental. Thus, business model interaction must also be managed. There are three main ways to do this:

a) Reconfigure your business model to add value in "open spaces" where there is little negative interaction with other industry players.

b) Build positive, complementary interactions when possible.

c) Reduce negative interactions or neutralize them through tactical choices.

To sum up, the added value that a firm generates is a direct consequence of the business model with which the firm competes. Business models should be the focus of managers seeking to effectively create and capture value. The future of the Catalan industrial base depends, to a large extent, on the ability of our business leaders to imagine, design, and implement new business models. 


\section{References}

Amit, R. and Zott, C. (2001), "Value Creation in e-Business," Strategic Management Journal, 22, pp. 493-520.

Brandenburger, Adam and Harborne Stuart (1996), "Value-based Business Strategy," Journal of Economics \& Management Strategy, 5, pp. 5-24.

Caldart, Adrian and Joan E. Ricart (2008), "Corporate Business Models: Unpacking the corporate effect on Performance,” working paper.

Casadesus-Masanell, Ramon and Jordan Mitchell (2006), “Irizar in 2005," HBS case 706-424 and Teaching Note 706-446.

Casadesus-Masanell, Ramon and David B. Yoffie (2007), "Wintel: Cooperation and Conflict," Management Science.

Casadesus-Masanell, Ramon and Pankaj Ghemawat (2006), "Dynamic Mixed Duopoly: A Model Motivated by Linux vs. Windows," Management Science, 52, No. 7, July, pp. 1072-1084.

Casadesus-Masanell, Ramon, Barry Nalebuff, and David B. Yoffie (2007), “Competing Complements," HBS Working Paper.

Casadesus-Masanell, Ramón and Joan E. Ricart "Competing through Business Models." forthcoming in Dagnino, G.B. (ed.), "Handbook of Research on Competitive Strategy." Cheltenham, UK, Edward Elgar.

Casadesus-Masanell, Ramon and Joan E. Ricart "Competing through Business Models (A)," Harvard Business School Module Note 708-452.

Casadesus-Masanell, Ramon and Joan E. Ricart "Competing through Business Models (B): Competitive Strategy vs. Business Models,” Harvard Business School Module Note 708475.

Casadesus-Masanell, Ramon and Joan E. Ricart "Competing through Business Models (C): Business Model Evaluation - Analysis in Interaction,” Harvard Business School Module Note 708-476.

Drucker, Peter (1954), “The Practice of Management,” Harper and Row Publishers.

Evans and Wurster (1997), "Strategy and the New Economics of Information," Harvard Business Review, Sep.-Oct.

Foster, Richard and Sarah Kaplan, (2001), "Creative Destruction from Built-to-Last to Built to Perform," Financial Times Prentice Hall, Aug.

Generalitat de Catalunya (2007), Departament d'Economia i Finances, and BBVA, Economia Catalana: Reptes de Futur, Barcelona.

Govindajaran, Vijay and Chris Trimble (2004), "Strategic Innovation and the Science of Learning," MIT Sloan Management Review, Winter.

Hart, Stuart and Clay Christensen (2002), "The great leap: Driving innovation from the base of the pyramid," Sloan Management Review, 44 (1), pp. 51-56. 
IBM Global Business Services (2006) "Expanding the Innovation Horizon: The Global CE0 Study 2006," IBM Corporation.

Kim, W. Chan and Renée Mauborgne (2005), Blue Ocean Strategy: How to Create Uncontested Market Space and Make Competition Irrelevant, "Harvard Business School Press."

London, Ted and Stuart Hart (2003), "Reinventing strategies for emerging markets: Beyond the transnational model," Journal of International Business Studies, Sept.

Magretta, J. (2002), “Why Business Models Matter, Harvard Business Review, May.

Malone, Thomas W. (2004), “The Future of Work,” Harvard Business School Press, Boston.

McGrath, Rita Gunther and Ian C. Macmillan (2005), "MarketBusters: 40 Strategic Moves That Drive Exceptional Business Growth,” Harvard Business School Press.

Porter, Michael (1996), "What Is Strategy?" Harvard Business Review.

Prahalad, C.K. and Stuart Hart (2002), "The Fortune at the Bottom of the Pyramid," Strategy \& Business, 26, pp. 2-14.

Prahalad, C.K. (2005), "The Fortune at the Bottom of the Pyramid: Eradicating Poverty through Profits," Wharton School Publishing, Philadelphia.

Prahalad, C.K. and Venkat Ramaswamy (2004), "The Future of Competition: Co-Creating Unique Value with Customers," Harvard Business School Press.

Ricart, Joan E. (2009), “Competint amb Models de Negoci,” Papers d'Economia Industrial, forthcoming.

Rivkin, Jan W. (2000), “Dogfight Over Europe: Ryanair (C),” HBS case 700-117.

Shafer, Scott M., H. Jeff Smith, and Jane C. Linder (2005), "The Power of Business Models," Business Horizons, 48, pp. 199-207.

Varian, H.R. and C. Shapiro (1999), "Information Rules: A Strategic Guide to the Network Economy," Harvard Business School Press.

Williamson, Oliver (1985), “The Economic Institutions of Capitalism,” The Free Press.

Yip, George S. (2004), "Using Strategy to Change your Business Model," Business Strategy Review, Vol. 15, 2, Summer.

Zott, C. and R. Amit (2006), "Exploring the Fit Between Business Strategy and Business Model: Implications for Firm Performance,". Working Paper (revised, May).

Zott, C. and R. Amit (2007), "Business Model Design and the Performance of Entrepreneurial Firms,” Organization Science, Vol. 18, 2, March-April, pp. 181-199. 


\section{Appendix}

Evaluation of a Business Model

To address the question of how effective a business model is, we divide the analysis into two parts. We first consider an organization's business model in isolation from those of other players with which it interacts and later move on to include interaction. While considering business models in isolation is artificial, the analysis of business model interaction adds enough complexity to justify the approach.

\section{Business Model Evaluation - Analysis in Isolation}

We begin by considering the business model of a focal organization, ignoring the fact that it is affected by those of other players. In other words, we consider an organization in an interaction vacuum and ask whether its business model delivers the goals that the organization is trying to accomplish. We say that a business model is effective if it allows the organization to reach its goals in isolation. Effectiveness can be assessed by careful consideration of four related desirable features: alignment to goal, reinforcement, virtuousness, and robustness.

Alignment to goal refers to business model choices delivering consequences that move the organization towards achieving its objectives. An organization may possess a terrific business model that works very smoothly. However, if the organization's goal is different from what the business model delivers, then the alignment to goal fails and the business model is just not appropriate.

Reinforcement means that choices complement each other well. Let A and B be two choices. In business model representations we sometimes write $\mathrm{A} \leftrightarrow \mathrm{B}$ to denote complementarity. We do this as 'shorthand' when $\mathrm{A}$ and $\mathrm{B}$ are indeed complementary and have the same direct consequences. A more elaborate diagram would have the entire chain from each choice to consequences.

Virtuousness refers to how well the business model allows the organization to attain its goals as time passes. This is a dynamic version of alignment to goal. To check for virtuousness, the key question is Does the business model make goal attainment easier as time goes by? For the answer to be positive, there must exist virtuous cycles closely related to the goals.

Robustness refers to the ability of the business model to sustain its effectiveness over time. Ghemawat (1991) identified four generic threats to sustainability: imitation, hold up, slack, and substitution. Thus, to check for robustness we ask: how well does the business model deal with each one of these threats?

\section{Business Model Evaluation - Analysis in Interaction}

Business models do not operate in a vacuum. The effectiveness of a business model depends to a large extent on the design of the business models of those other players with which it interacts. Intuitively, two organizations interact when performance depends on the presence of the other. Put more simply: two organizations interact when they affect one another. Interaction can be with competitors, suppliers, complementors, or distributors (just to mention a 
few possibilities). Moreover, interaction may entail competition or cooperation and both may be for value capture or for value creation.

- There are two different but related concepts of interaction: Tactical interaction and Strategic interaction. Before discussing interaction, however, we need to present the notion of business model interdependence: Business models of two firms are interdependent when some consequences are common to both firms' models. In other words, the business models of two firms are interdependent when they "touch" each other.

Tactical Interaction: Tactical interaction refers to organizations affecting each other by acting within the bounds set by their business models. If the business models of the firms under consideration are not interdependent, then there cannot be tactical interaction. The links between business models allow tactics of one firm to affect the working of the other firm's model. When contact points are absent, tactics have no effect on each other. Of course, even in the absence of interdependence, there is a direct effect of tactics on the organization employing them. Aggressiveness refers to the capacity of a firm to affect the working of other players' business models by use of tactics. Conversely, defensiveness refers to how well a firm can fend off or take advantage of "moves" of players with which it interacts given its business model.

The business model of firm A is said to be consistent for a given interaction with $\mathrm{B}$, if it displays an appropriate balance between aggressiveness and defensiveness. Firm A's business model is consistent (overall) if it is consistent for all relevant interactions it may face. Consistency therefore captures the capacity of the business model to continue achieving its goals, taking into account the possible strategic interactions that may potentially take place.

While robustness is a property of business models in isolation (as it is based on features that help the business model deal with uncertain events, imitation, or value appropriation by others via slack or hold-up), consistency is about the strength of the business model in interaction. Both robustness and consistency are dynamic concepts but truly distinct in character.

Strategic Interaction: Strategic interaction refers to how changes in a firm's business model affect the working of another firm's business model. Strategic interaction is concerned with the choice of policies, assets, and governance structures. And, while organizations do not affect each other directly through changes in their business models, there is an indirect effect through the resulting business models as new intensity levels of interdependence and tactical interaction ensue.

Thus, as it concerns competitive (and cooperative) interaction, there are two ways in which strategies affect outcomes. First, strategies affect the degree of business model interdependence present between any two players. In other words, business model interdependence is endogenous. ${ }^{15}$ Second, strategies determine the extent to which business models exhibit (tactical) aggressiveness and defensiveness. It is important to note that the intensity of interdependence, aggressiveness, and defensiveness between players A and B are not chosen by A alone or B alone, but depend (simultaneously) on the strategies followed by both A and B; that is, their strategic interactions.

\footnotetext{
${ }^{15}$ Note that most of the literature on industrial organization assumes exogenous interdependence.
} 